\title{
Magnetic Nanoparticles Interaction with Humic Acid: In the presence of Surfactants
}

\section{Supporting Information}

Zhi Tang ${ }^{\dagger, \star}$, Xiaoli Zhao ${ }^{\dagger,{ }^{\dagger},}$, Tianhui Zhao*, Hao Wang ${ }^{\ddagger}$, Peifang Wang ${ }^{\S}$, Fengchang $\mathrm{Wu}^{\text {t*}^{*}}$, and John P. Giesy ${ }^{\mathfrak{f}}$

\# State Key Laboratory of Environmental Criteria and Risk Assessment, Chinese Research Academy of Environmental Sciences, Beijing 100012, China;

${ }^{\S}$ Key Laboratory of Integrated Regulation and Resources Development on Shallow Lakes, Ministry of Education, College of Environment, Hohai University, Nanjing 210098, People's Republic of China

${ }^{£}$ Department of Veterinary Biomedical Sciences and Toxicology Centre, University of Saskatchewan, Saskatoon, Saskatchewan, Canada.

Author Contributions: †These authors contributed equally to this work

* To whom correspondence may be addressed

Telephone number: $+86-10-84915312$

Fax number: +86-10-84931804

E-mail: zhaoxiaoli_zxl@126.com,wufengchang@vip.skleg.cn.

Supporting information in Page S1-S10 consists of two tables and six Figures and includes Parameters of isotherms and kinetic of adsorption, characterization of HA adsorbed on surface of $\mathrm{Fe}_{3} \mathrm{O}_{4}$ NPs in the presence of surfactants including adsorption kinetic, morphology of the nanoparticles, isoelectric point. Fourier transform infrared and X-ray photoelectron spectroscopy of HA adsorbed on surfaces of $\mathrm{Fe}_{3} \mathrm{O}_{4} \mathrm{NPs}$ and $\mathrm{Fe}_{3} \mathrm{O}_{4} \mathrm{NPs} /$ surfactants. This material is available free of charge via the Internet at http://pubs.acs.org. 


\section{Table of Content}

Table S1. Langmuir Freundlich isotherms parameters for $\mathrm{HA}$ adsorption on $\mathrm{Fe}_{3} \mathrm{O}_{4}$ NPs

Table S2. The adsorption kinetic model rate of adsorption of $\mathrm{HA}$ at different adsorption stage of $\mathrm{Fe}_{3} \mathrm{O}_{4}$ NPs/CTAB (pH 10.0) and $\mathrm{Fe}_{3} \mathrm{O}_{4}$ NPs/SDS (pH $5.0)$

Figure S1. $\zeta$-potential of $\mathrm{Fe}_{3} \mathrm{O}_{4} \mathrm{NPs}$ in different $\mathrm{pH}$ conditions. Amount of $\mathrm{Fe}_{3} \mathrm{O}_{4}$ NPs: $10 \mathrm{mg}$; Solution volume: $100 \mathrm{~mL}$

Figure S2. TEM image of $\mathrm{Fe}_{3} \mathrm{O}_{4}$ NPs (a), $\mathrm{Fe}_{3} \mathrm{O}_{4} \mathrm{NPs} / \mathrm{HA}(\mathrm{b}), \mathrm{Fe}_{3} \mathrm{O}_{4}$ NPs/CTAB (c), $\mathrm{Fe}_{3} \mathrm{O}_{4} \mathrm{NPs} / \mathrm{CTAB} / \mathrm{HA}(\mathrm{d})$

Figure S3. Pseudo-second-order kinetic curves of adsorption of HA on different adsorption stage of $\mathrm{Fe}_{3} \mathrm{O}_{4}$ NPs/CTAB (at $\mathrm{pH}$ 10.0) (a) and $\mathrm{Fe}_{3} \mathrm{O}_{4}$ NPs/SDS (at pH 5.0) (b). Operation in the batch mode. Amount of $\mathrm{Fe}_{3} \mathrm{O}_{4}$ NPs: $10 \mathrm{mg}$. Solution volume: $100 \mathrm{~mL}$. Concentration of HA: $30 \mathrm{mg} / \mathrm{L}$

Figure S4. FTIR spectra for $\mathrm{HA}, \mathrm{Fe}_{3} \mathrm{O}_{4} \mathrm{NPs}$ and $\mathrm{Fe}_{3} \mathrm{O}_{4} \mathrm{NPs} / \mathrm{HA}$

Figure S5. FTIR spectra of HA adsorbed on $\mathrm{Fe}_{3} \mathrm{O}_{4}$ NPs in the presence of CTAB (a) and SDS (b)

Figure S6. O1s for $\mathrm{Fe}_{3} \mathrm{O}_{4} \mathrm{NPs}, \mathrm{Fe}_{3} \mathrm{O}_{4} \quad \mathrm{NPs} / \mathrm{HA}, \mathrm{Fe}_{3} \mathrm{O}_{4}$ NPs/CTAB and $\mathrm{Fe}_{3} \mathrm{O}_{4}$ NPs/CTAB/HA (a); N1s for $\mathrm{Fe}_{3} \mathrm{O}_{4} \quad \mathrm{NPs}, \quad \mathrm{Fe}_{3} \mathrm{O}_{4} \quad \mathrm{NPs} / \mathrm{HA}, \quad \mathrm{Fe}_{3} \mathrm{O}_{4}$ NPs/CTAB and $\mathrm{Fe}_{3} \mathrm{O}_{4}$ NPs/CTAB/HA (b); C1s for $\mathrm{Fe}_{3} \mathrm{O}_{4} \mathrm{NPs}, \mathrm{Fe}_{3} \mathrm{O}_{4}$ NPs/HA, $\mathrm{Fe}_{3} \mathrm{O}_{4}$ NPs/CTAB and $\mathrm{Fe}_{3} \mathrm{O}_{4}$ NPs/CTAB/HA (c) 
Table S1. Langmuir Freundlich isotherms parameters for HA adsorption on $\mathrm{Fe}_{3} \mathrm{O}_{4} \mathrm{NPs}$

\begin{tabular}{ll}
\hline Parameters & $\begin{array}{l}\text { Solution temperature (303 K) } \\
\text { Solution } \mathrm{pH}(5.0)\end{array}$ \\
\hline Isotherm & Langmuir \\
\hline & 120.3 \\
$q_{m} / \mathrm{mg} \mathrm{g}^{-1}$ & 0.03987 \\
$K_{L} / \mathrm{L} \mathrm{mg}^{-1}$ & 0.977 \\
$r^{2}$ & Freundlich \\
& 3.7988 \\
$K / \mathrm{mg} \mathrm{g}^{-1}\left(\mathrm{~L} \mathrm{mg}^{-1}\right)^{1 / \mathrm{n}}$ & 1.33 \\
$n$ & 0.958 \\
\hline
\end{tabular}


Table S2. The adsorption kinetic model rate of adsorption of $\mathrm{HA}$ at different adsorption stage of $\mathrm{Fe}_{3} \mathrm{O}_{4} \mathrm{NPs} / \mathrm{CTAB}$ (pH 10.0) and $\mathrm{Fe}_{3} \mathrm{O}_{4} \mathrm{NPs} / \mathrm{SDS}$ (pH 5.0)

\begin{tabular}{ccccc}
\hline & \multicolumn{4}{c}{ The adsorption kinetic model rate Pseudo-second-order } \\
\cline { 2 - 5 } & $\mathrm{k}_{2} \mathrm{~g}\left(\mathrm{mg}^{-1} \mathrm{~min}^{-1)}\right.$ & $\mathrm{q}_{\mathrm{e}}\left(\mathrm{mg} \mathrm{g}^{-1)}\right.$ & $\mathrm{h}_{0}\left(\mathrm{mg} \mathrm{g}^{-1} \mathrm{~min}^{-1}\right)$ & $\mathrm{r}$ \\
\hline $20 \mathrm{mg} \mathrm{CTAB}$ & 1.107 & 61.73 & 42.19 & 0.9967 \\
$40 \mathrm{mg} \mathrm{CTAB}$ & 3.018 & 153.85 & 714.29 & 0.9996 \\
$10 \mathrm{mg} \mathrm{SDS}$ & 5.565 & 44.05 & 10.799 & 0.9982 \\
\hline
\end{tabular}

Pseudo-second-order isotherm: $\frac{t}{q_{t}}=\frac{1}{k_{2} q_{e}{ }^{2}}+\frac{1}{q_{e}} t$

where $k_{2}$ is the rate constant of adsorption (in $\mathrm{g} \mathrm{mg}^{-1} \mathrm{~min}^{-1}$ ), $q_{t}$ is the amount of HA adsorbed by adsorbent at any time $\left(\mathrm{mg} \mathrm{g}^{-1}\right), q_{e}$ is equilibrium adsorption capacity $\left(\mathrm{mg} \mathrm{g}^{-1}\right)$. And the initial sorption rate, $h_{\mathrm{o}}\left(\mathrm{mg} \mathrm{g}^{-1} \mathrm{~min}^{-1}\right)$ can be defined as

$$
h_{o}=k_{2} q_{e}^{2} \quad(t \rightarrow 0)
$$

Both $k_{2}$ and $h_{\mathrm{o}}$ could be determined experimentally by plotting of $t / q_{t}$ against $t$.

The initial rapid adsorption was presumably due to electrostatic attraction. The slow adsorption in the later stage represented a gradual uptake of HA at the inner surface by complexation. The constant $k_{2}$, the initial sorption rate $h_{o}$ and equilibrium adsorption capacity $\left(q_{e}\right)$ obtained from the slope and intercept of plots were presented in Table 2. The results showed an increase in $k_{2}$ values and $h_{o}$ and $q_{e}$ values at greater concentrations of HA. 


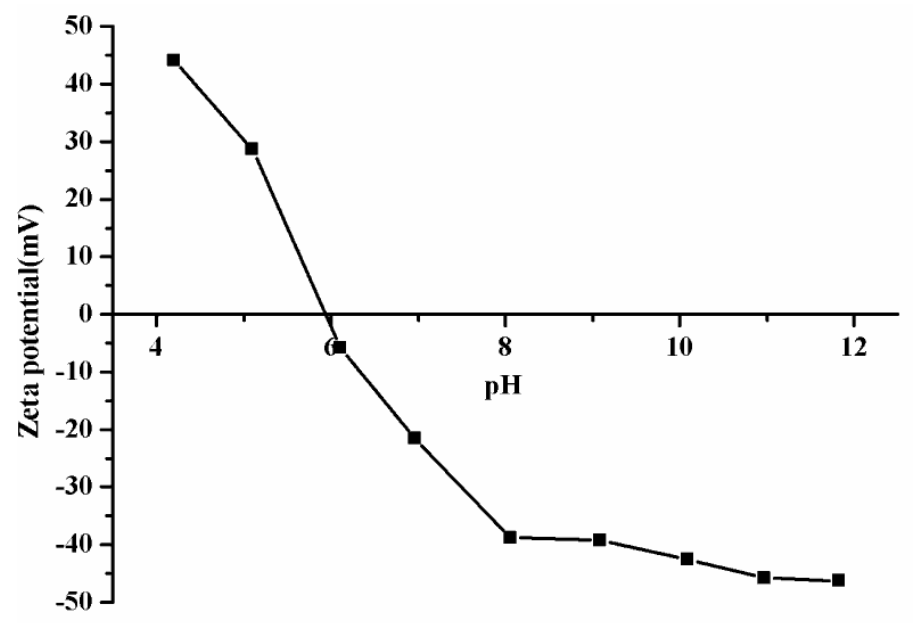

Fig S1. ל-potential of $\mathrm{Fe}_{3} \mathrm{O}_{4} \mathrm{NPs}$ in different $\mathrm{pH}$ conditions. Amount of $\mathrm{Fe}_{3} \mathrm{O}_{4} \mathrm{NPs}$ : $10 \mathrm{mg}$; Solution volume: $100 \mathrm{~mL}$. 
TEM image. From the TEM images, it can be seen that $\mathrm{Fe}_{3} \mathrm{O}_{4}$ NPs exhibited more aggregation with irregular shapes (Fig. S2a), and after the surface of $\mathrm{Fe}_{3} \mathrm{O}_{4} \mathrm{NPs}$ surface was coated with $\mathrm{HA}$ and wrapped around $\mathrm{Fe}_{3} \mathrm{O}_{4}$ NPs in a quasi-spherical shape, the $\mathrm{Fe}_{3} \mathrm{O}_{4}$ NPs/HA had nearly uniform distribution of particle size of approximately $10 \mathrm{~nm}$, and the degree of aggregation was also less (Fig. S2b). This result was consistent with results of previous research. ${ }^{1}$ TEM images of $\mathrm{Fe}_{3} \mathrm{O}_{4}$ NPs/CTAB and $\mathrm{Fe}_{3} \mathrm{O}_{4}$ NPs/CTAB/HA are shown in Fig. S2c, S2d. The $\mathrm{Fe}_{3} \mathrm{O}_{4}$ NPs/CTAB exhibited aggregation to some extent with a regular shape (Fig.S2c), and the level of aggregation intermediate of that for $\mathrm{Fe}_{3} \mathrm{O}_{4}$ NPs and $\mathrm{Fe}_{3} \mathrm{O}_{4} \mathrm{NPs} / \mathrm{HA}$. The TEM image of $\mathrm{Fe}_{3} \mathrm{O}_{4}$ NPs/CTAB/HA (Fig. S2d) demonstrated a unique phenomenon compare with others, in that the shape was more regular compared with the $\mathrm{Fe}_{3} \mathrm{O}_{4}$ NPs which directly coated by HA or surfactants.

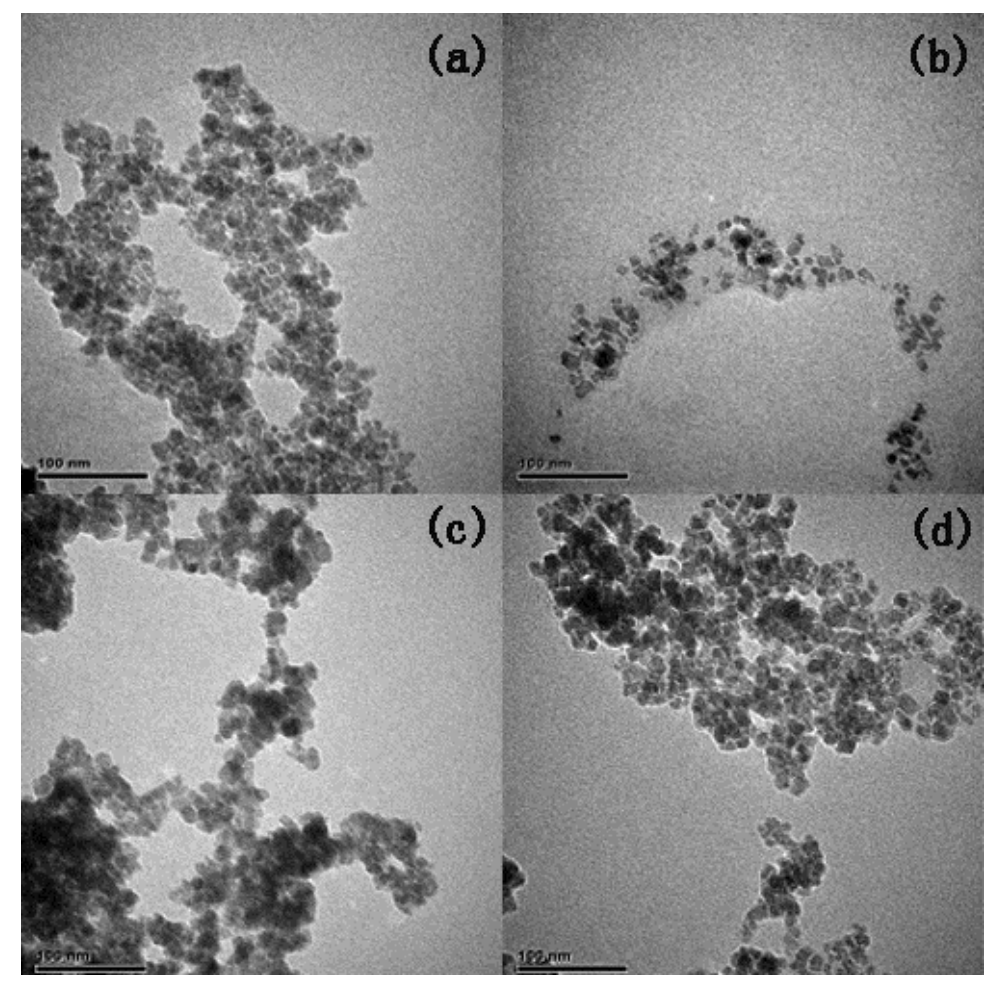

Fig S2. TEM image of $\mathrm{Fe}_{3} \mathrm{O}_{4} \mathrm{NPs}(\mathrm{a}), \mathrm{Fe}_{3} \mathrm{O}_{4} \mathrm{NPs} / \mathrm{HA}(\mathrm{b}), \mathrm{Fe}_{3} \mathrm{O}_{4} \mathrm{NPs} / \mathrm{CTAB}$ (c), $\mathrm{Fe}_{3} \mathrm{O}_{4}$ NPs/CTAB/HA (d). 

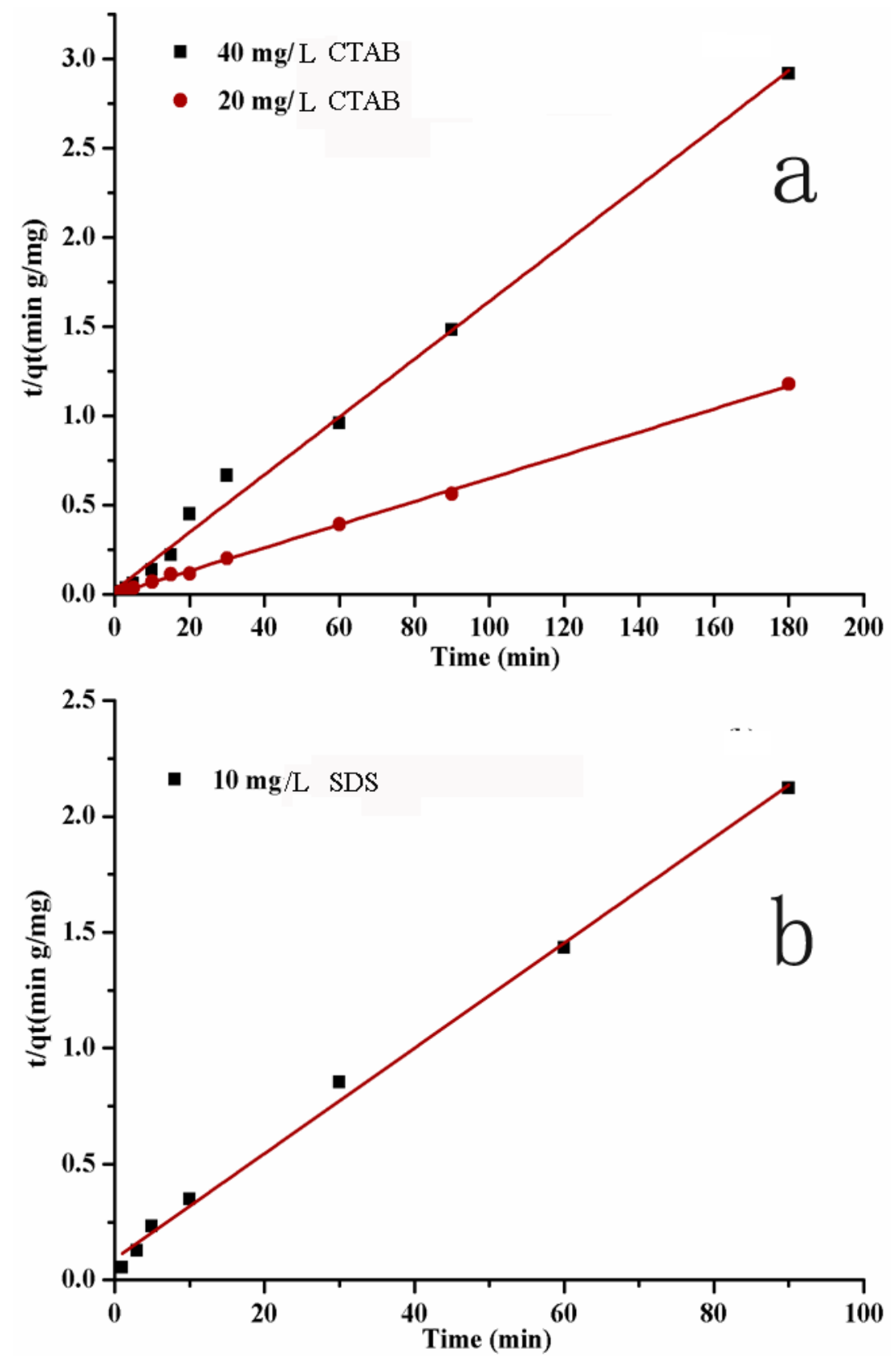

Fig S3. Pseudo-second-order kinetic curves of adsorption of HA on different adsorption stage of $\mathrm{Fe}_{3} \mathrm{O}_{4} \mathrm{NPs} / \mathrm{CTAB}$ (at $\mathrm{pH} \mathrm{10.0)}$ (a) and $\mathrm{Fe}_{3} \mathrm{O}_{4} \mathrm{NPs} / \mathrm{SDS}$ (at pH 5.0) (b). Operation in the batch mode. Amount of $\mathrm{Fe}_{3} \mathrm{O}_{4}$ NPs: $10 \mathrm{mg}$. Solution volume: $100 \mathrm{~mL}$. Concentration of HA: $30 \mathrm{mg} / \mathrm{L}$. 


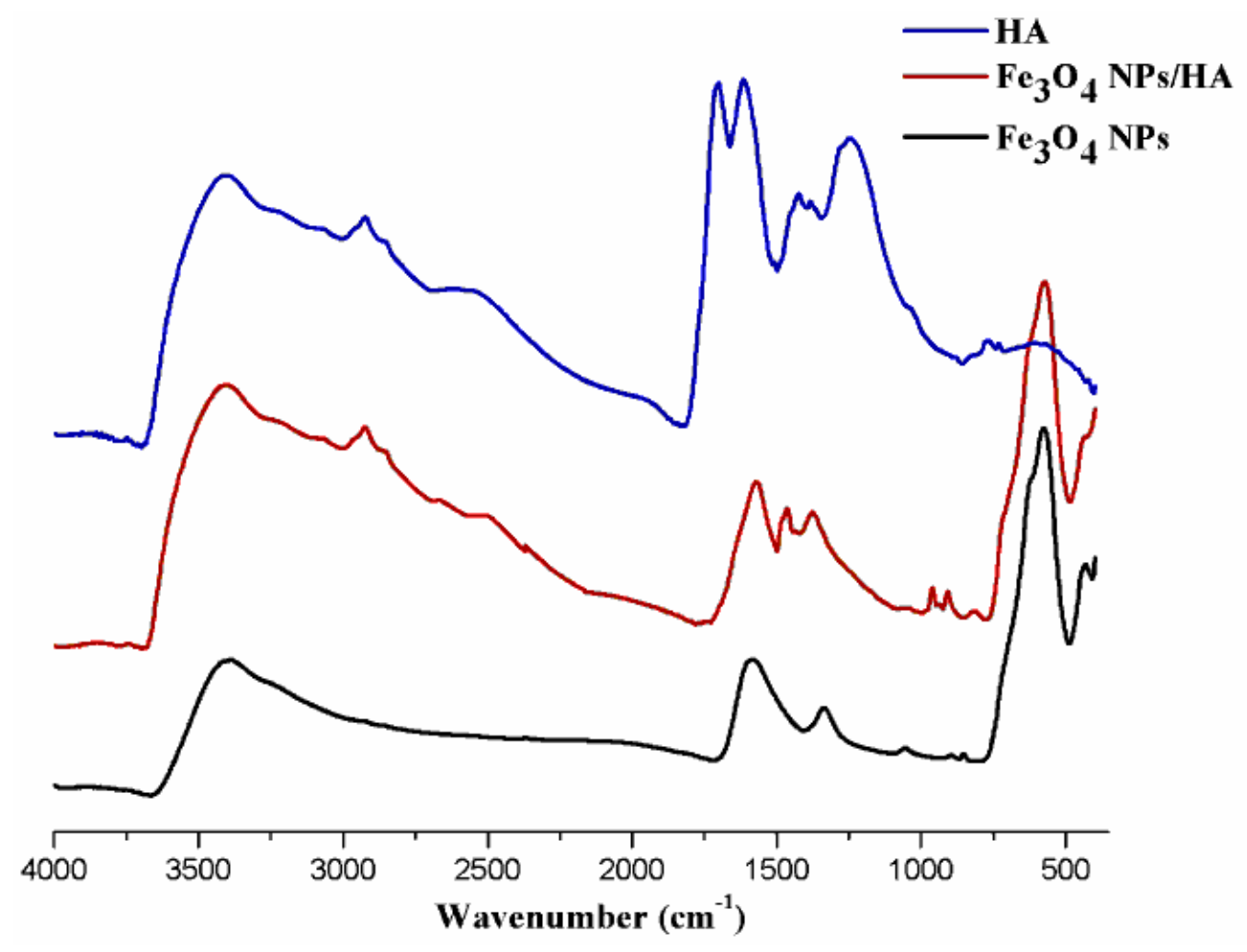

Fig S4. FTIR spectra for $\mathrm{HA}, \mathrm{Fe}_{3} \mathrm{O}_{4} \mathrm{NPs}$ and $\mathrm{Fe}_{3} \mathrm{O}_{4} \mathrm{NPs} / \mathrm{HA}$. 


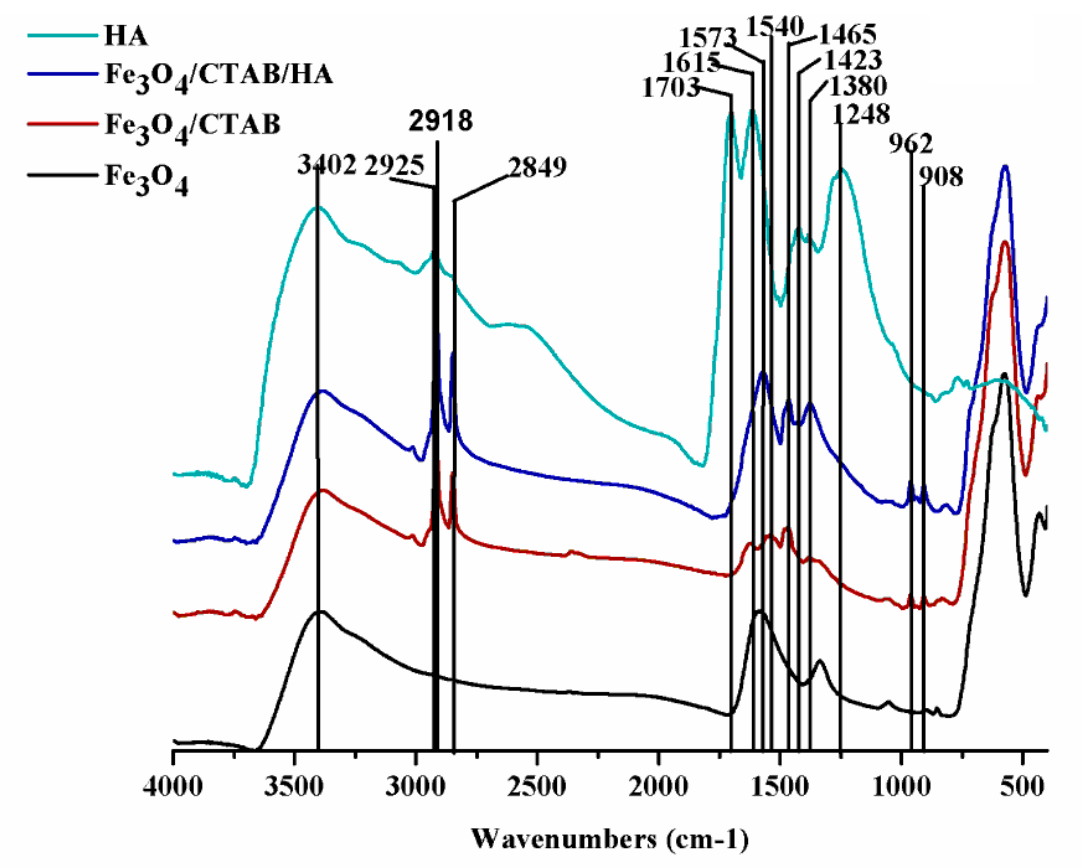

a

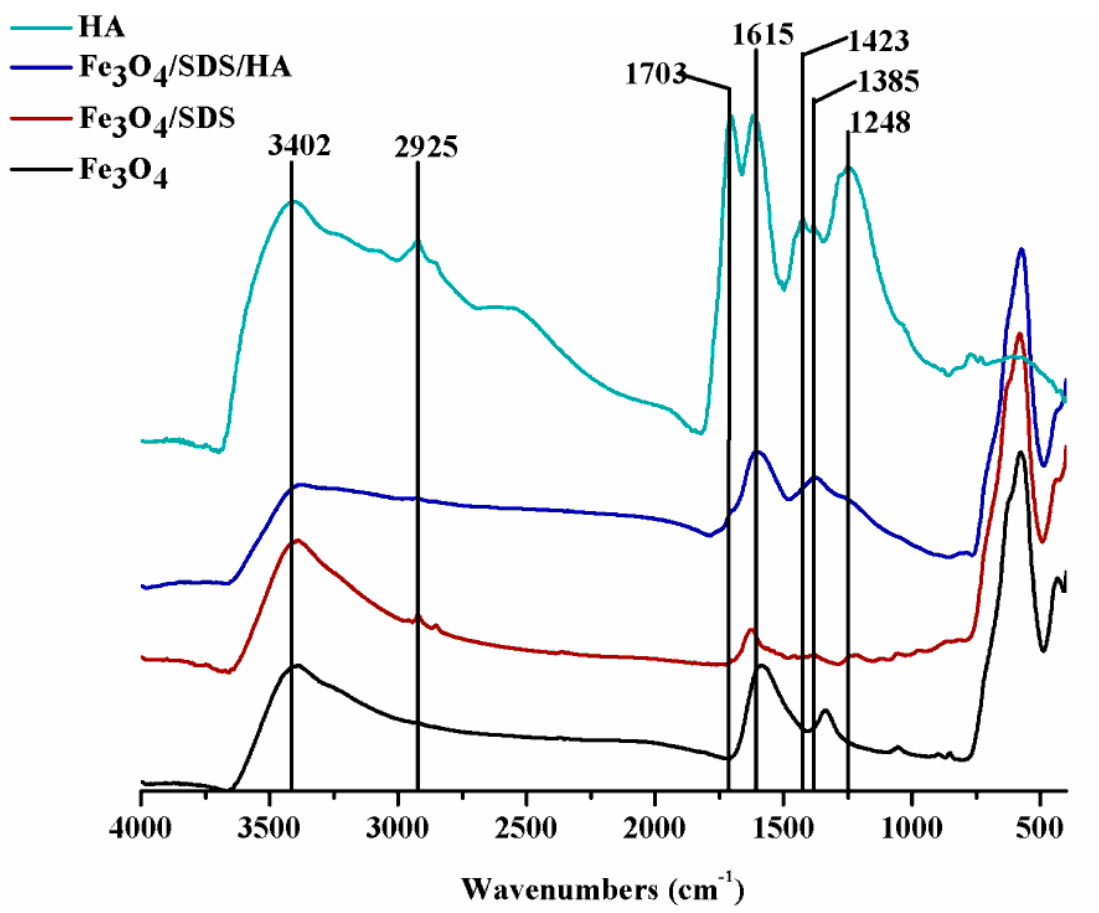

Fig S5. FTIR spectra of $\mathrm{HA}$ adsorbed on $\mathrm{Fe}_{3} \mathrm{O}_{4} \mathrm{NPs}$ in the presence of CTAB (a) and SDS (b) 

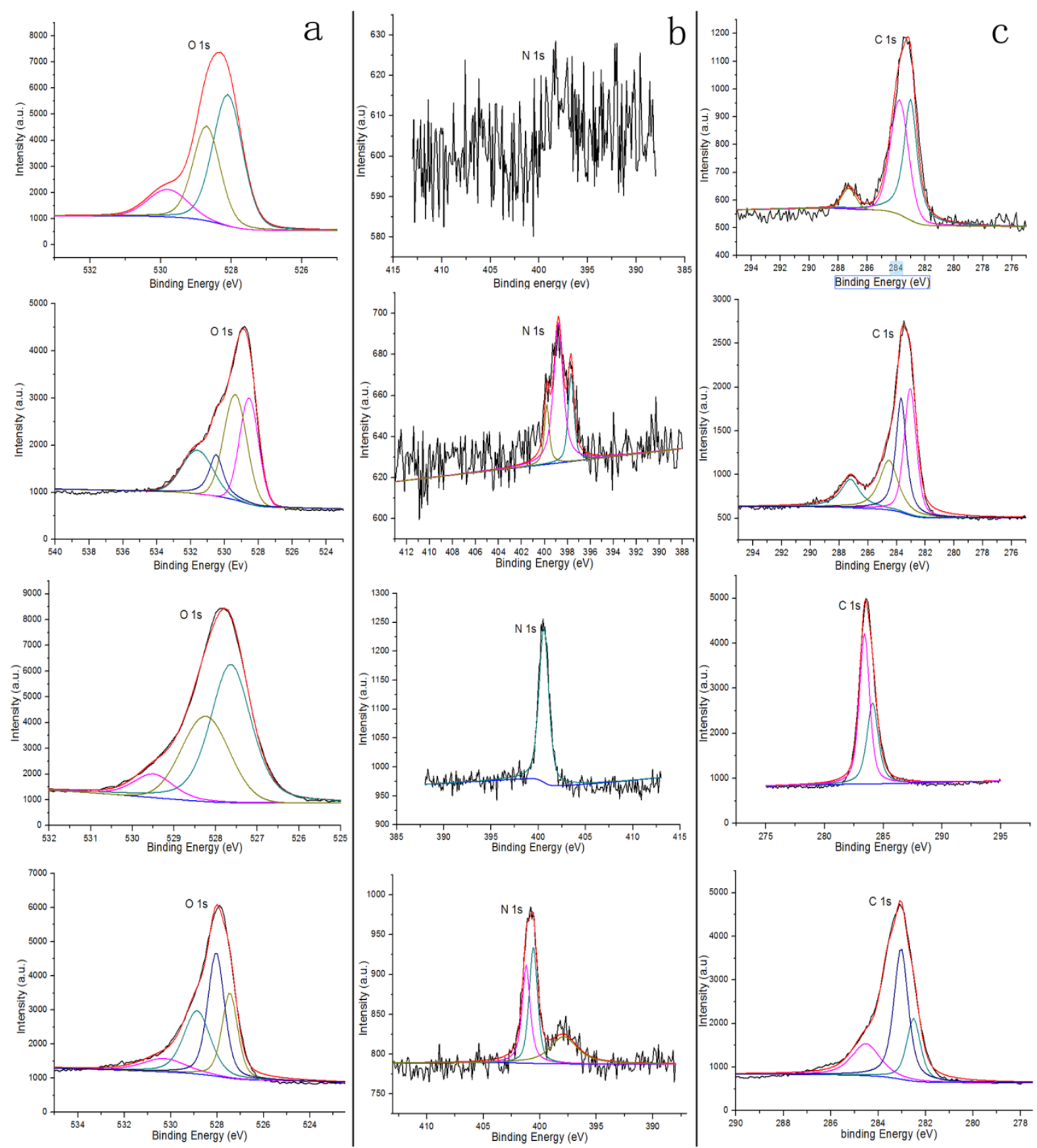

Fig S6. O1s for $\mathrm{Fe}_{3} \mathrm{O}_{4} \mathrm{NPs}, \mathrm{Fe}_{3} \mathrm{O}_{4} \mathrm{NPs} / \mathrm{HA}, \mathrm{Fe}_{3} \mathrm{O}_{4} \mathrm{NPs} / \mathrm{CTAB}$ and $\mathrm{Fe}_{3} \mathrm{O}_{4}$ $\mathrm{NPs} / \mathrm{CTAB} / \mathrm{HA}$ (a); N1s for $\mathrm{Fe}_{3} \mathrm{O}_{4} \mathrm{NPs}, \mathrm{Fe}_{3} \mathrm{O}_{4} \mathrm{NPs} / \mathrm{HA}, \mathrm{Fe}_{3} \mathrm{O}_{4} \mathrm{NPs} / \mathrm{CTAB}$ and $\mathrm{Fe}_{3} \mathrm{O}_{4} \mathrm{NPs} / \mathrm{CTAB} / \mathrm{HA}$ (b); C1s for $\mathrm{Fe}_{3} \mathrm{O}_{4} \mathrm{NPs}, \mathrm{Fe}_{3} \mathrm{O}_{4} \mathrm{NPs} / \mathrm{HA}, \mathrm{Fe}_{3} \mathrm{O}_{4} \mathrm{NPs} / \mathrm{CTAB}$ and $\mathrm{Fe}_{3} \mathrm{O}_{4} \mathrm{NPs} / \mathrm{CTAB} / \mathrm{HA}(\mathrm{c})$. 


\section{References}

1. Niu, H. Y.; Zhang, D.; Zhang, S. X.; Zhang, X. L.; Meng, Z. F.; Cai, Y. Q. Humic acid coated $\mathrm{Fe} 3 \mathrm{O} 4$ magnetic nanoparticles as highly efficient Fenton-like catalyst for complete mineralization of sulfathiazole. J. Hazard. Mater. 2011, 190 (1), 559-565. 